\title{
Investigation of Physical Climate Inside the Lake Wessel Chamber
}

\author{
Z. DAMiJAN*, C. KASPRZAK \\ Department of Mechanics and Vibroacoustics, Faculty of Mechanical Engineering and Robotics \\ AGH University of Science and Technology, al. Mickiewicza 30, 30-059 Kraków, Poland
}

\begin{abstract}
This study summarizes the research results and environmental measurement data collected in the Lake Wessel Chamber in the salt mine Wieliczka. This chamber is a place where patients who suffer from upper airways diseases are treated during 14-days' therapeutic periods. Therapeutic properties of certain caverns and chambers have been well known since the 1950s while the therapeutic values of underground space, particularly the atmosphere, were discovered in the 1960s and the term "subterranotherapy' was subsequently coined up. The treatment is applied there whereby patients, mostly those suffering from respiratory diseases, are subjected to specific physical, chemical and biological stimuli which are available only underground, those stimuli featuring a complex natural structure and synergic biodynamics. Major features of the underground atmosphere determining its therapeutic properties include the presence of natural aerosols, electroaerosols, temperature, humidity, air circulation, ions, light radiation, electromagnetics, gravitation forces and $\mathrm{pH}$ of the atmosphere. This study summarises the radiation measurement data (concentrations of potential energy alpha $C \alpha)$ and air composition measurements $\left(\mathrm{SO}_{2}\right.$, $\mathrm{H}_{2} \mathrm{~S}, \mathrm{CO}, \mathrm{CO}_{2}$, NO contents). the measurement procedures were in line with the relevant standards and regulations.
\end{abstract}

PACS numbers: 92.60.Sz, 92.70.Kb

\section{Introduction}

Therapeutic properties of certain caverns and chambers have been well known since the 1950s while the therapeutic values of underground space, particularly the atmosphere, were discovered in the 1960s and the term "subterranotherapy" was coined up. The treatment is applied there whereby patients, mostly those suffering from respiratory disorders, are subjected to specific physical, chemical and biological stimuli which are available only underground, those stimuli featuring a complex natural structure and synergic biodynamics. Major features of the underground atmosphere determining its therapeutic properties include the presence of natural aerosols, electroaerosols, temperature, humidity, air circulation, ions, light radiation, electromagnetics, gravitation forces and $\mathrm{pH}$ index of the atmosphere. These discoveries prompted the adaptation of mine excavations and chambers in the salt mine 'Wieliczka' for the needs of subterranotherapy. The first subterranotherapy centre was established in an underground salt chamber in the mine "Wieliczka" in 1958 , later it was transformed into a sanatorium and then into a hospital open all years round. Systematic analyses of the physical climate in the Lake Wessel Chamber were last carried out in the 1960s.

The salt mine Wieliczka has a unique microclimate featuring high humidity and high contents of sodium chloride, constant temperature $\left(9-12^{\circ} \mathrm{C}\right)$, constant pressure, presence of ions, light radiation, high contents of manganese, magnesium and calcium in the atmosphere, which

* corresponding author; e-mail: damijan@imir.agh.edu.pl encourages its therapeutic use. For patients who suffer from respiratory diseases can be offered treatment in the Lake Wessel Chamber. The Chamber and the incoming galleries: Prokopowicz and Ferdynand are situated on the third level of the Wieliczka salt mine. The Lake Wessel Chmaber was excavated in the 19th century at the depth of $135 \mathrm{~m}$, its total volume approaches $18500 \mathrm{~m}^{3}$. The Chamber is situated in the east-central part of the excavation, about $500 \mathrm{~m}$ to the east of the main shaft "Daniłowicz". The chamber is oblong in shape and is surrounded by platforms allowing visitors to walk around the lake, situated in the central part of the chamber.

Wieliczka was the world-wide pioneer of subterranotherapy. In 1963 the first Research Association of Subterranotherapy was established there by Prof. Skulimowski [1-3]. In 1958 the first subterranotherapy centre was set up in underground salt chambers in Wieliczka, later transformed into a sanatorium open all year round. Unlike other treatment centres and sanatoriums, subterranotherapy still remains the basic therapeutic method there. It is worthwhile to mention that the methods and techniques of subterranotherapy, developed by Prof. Skulimowski in Wieliczka, have been also adopted in Russia, Romania and Bulgaria, where similar underground treatment centres have been opened. The methods are also used in Hungary, Austria, Slovakia and in the Czech Republic [4].

The Rehabilitation and Treatment Centre organises 14 days' sojourns for patients in an unforgettable place: a salt chamber by the Wessel Lake, $135 \mathrm{~m}$ underground.

Prior to the 14 days' treatment period patients are given the medical examination in the Treatment Centre. The qualification procedure being completed, the 
14 day's treatment period begins. For a fortnight, patients spend $6.5 \mathrm{~h}$ a day inside the salt chamber (Sundays are free from any medical procedures), supervised by qualified medical personnel (doctors, nurses, physiotherapists). The treatment procedure in the Lake Wessel Chamber involves active rehabilitation (breathing exercises, breathing control, correction of breathing patterns), learning the diaphragmatic respiration, training of respiratory muscles and bronchial tree treatment. No tests of acoustic or meteorological conditions were performed while the patients remained inside the Lake Wessel Chamber $[5,6]$.

Major features of the underground atmosphere determining its therapeutic properties include the presence of natural aerosols, electroaerosols, temperature, humidity, air circulation, ions, light radiation, electromagnetics, gravitation forces and $\mathrm{pH}$ of the atmosphere.

This study summarises the radiation measurement data (concentrations of potential energy alpha $C \alpha$ ) and air composition measurements $\left(\mathrm{SO}_{2}, \mathrm{H}_{2} \mathrm{~S}, \mathrm{CO}, \mathrm{CO}_{2}, \mathrm{NO}\right.$ contents). The measurement procedures were in line with the relevant standards and regulations.

\section{Experimental procedure}

Radiation measurements were taken in accordance with the regulations currently in force:

- Regulation by the Minister of Economy of 28th June 2002 relating to work safety, plant operation and fire prevention measures in underground mines (Journal of Laws no 139, $2^{\text {nd }}$ Sept 2002, item 1169)

- Regulation by the Council of Ministers of 18th Jan 2005 concerning the admissible doses of ionizing radiation (Journal of Laws no 20, 3rd Feb 2005, item 168)

Measurements were taken with the radiation meter RGR-13 commonly used in mines.

TABLE I

Measured air components. TLV — threshold limit value, TLV-TWA — time weighted concentrations TLV.

\begin{tabular}{l|c|c|c|c}
\hline \hline \multicolumn{1}{c|}{ Component } & & TLV & TLV-TWA & $\begin{array}{c}\text { Limit of } \\
\text { determination (lod) }\end{array}$ \\
\hline Carbon monoxide & $\mathrm{CO}$ & $30 \mathrm{mg} / \mathrm{m}^{3}$ & $180 \mathrm{mg} / \mathrm{m}^{3}$ & $1.17 \mathrm{mg} / \mathrm{m}^{3}$ \\
Nitrogen oxide & $\mathrm{NO}$ & $5 \mathrm{mg} / \mathrm{m}^{3}$ & $10 \mathrm{mg} / \mathrm{m}^{3}$ & $0.191 \mathrm{mg} / \mathrm{m}^{3}$ \\
Sulfur dioxide & $\mathrm{SO}_{2}$ & $2 \mathrm{mg} / \mathrm{m}^{3}$ & $5 \mathrm{mg} / \mathrm{m}^{3}$ & $0.266 \mathrm{mg} / \mathrm{m}^{3}$ \\
Hydrogen sulfide & $\mathrm{H}_{2} \mathrm{~S}$ & $10 \mathrm{mg} / \mathrm{m}^{3}$ & $20 \mathrm{mg} / \mathrm{m}^{3}$ & $0.142 \mathrm{mg} / \mathrm{m}^{3}$ \\
Carbon dioxide & $\mathrm{CO}_{2}$ & $1.0 \%, 18000 \mathrm{mg} / \mathrm{m}^{3}$ & $1.0 \%, 18000 \mathrm{mg} / \mathrm{m}^{3}$ & $1800 \mathrm{mg} / \mathrm{m}^{3}$
\end{tabular}

Table I summarizes the air composition parameters, TLV, TLV-TWA and the relevant limits of determination. Measurements were taken in accordance with the procedure specified in the technical standard $\mathrm{PN}-89$ / Z-04008/07, Air quality protection". Principles of air sample collection in the working environment. Interpretation of results" and with the Regulation by the Minister of Labour and Welfare Policy of 29 Nov 2002 (Journal of Laws no 21, item 1833, 28th Dec 2002) specifying the highest admissible contents and intensity of harmful factors at work, as well as with the Regulation by the Minister of Economy of 28th June 2002 relating to work safety, plant operation and fire prevention measures in underground mines (Journal of Laws no 139, 2nd Sept 2002, item 1169).

Measurements were taken with the use of specialist metering devices: TOX-CO, TOX-NO, TOX-CO2, MG7-SO2, MG7-H2S. These are all portable devices intended for measuring trace concentrations (ppm) of toxic substances: carbon monoxide, nitrogen oxide, carbon dioxide, sulfur dioxide and hydrogen sulfide. Tests in the
Lake Wessel Chamber were repeated three times, in subsequent weeks.

\section{Results}

Potential energy concentrations $C \alpha$ inside the Lake Wessel Chamber are summarized in Table II.

TABLE II

Measurements of potential energy concentrations $C \alpha$.

\begin{tabular}{|c|c|c|c|c|}
\hline & Control point & $\begin{array}{c}\text { Mean } \\
\text { concentration } \\
C \alpha\left[\mu \mathrm{J} / \mathrm{m}^{3}\right]\end{array}$ & $\begin{array}{c}\text { Effective } \\
\text { dose } \\
{[\mathrm{mSv}]}\end{array}$ & $\begin{array}{c}\text { Effective dose } \\
\text { with the natural } \\
\text { background } \\
\text { accounted for } \\
{[\mathrm{mSv}]}\end{array}$ \\
\hline 1. & $\begin{array}{l}\text { Doctors' duty } \\
\text { room }\end{array}$ & 0.339 & 0.85 & 0.36 \\
\hline 2. & Gallery & 0.412 & 1.04 & 0.55 \\
\hline 3. & $\begin{array}{l}\text { In the incoming } \\
\text { air stream }\end{array}$ & 0.225 & 0.57 & 0.08 \\
\hline 4. & $\begin{array}{l}\text { In the escaping } \\
\text { air stream }\end{array}$ & 0.493 & 1.24 & 1.24 \\
\hline
\end{tabular}


TABLE III

Air composition inside the Lake Wessel Chamber.

\begin{tabular}{c|c|c|c|c|c}
\hline \hline Measurement no & $\begin{array}{c}\mathrm{CO}_{2} \\
{[\%]}\end{array}$ & $\begin{array}{c}\mathrm{CO} \\
{\left[\mathrm{mg} / \mathrm{m}^{3}\right]}\end{array}$ & $\begin{array}{c}\mathrm{NO} \\
{\left[\mathrm{mg} / \mathrm{m}^{3}\right]}\end{array}$ & $\begin{array}{c}\mathrm{SO}_{2} \\
{\left[\mathrm{mg} / \mathrm{m}^{3}\right]}\end{array}$ & $\begin{array}{c}\mathrm{H}_{2} \mathrm{~S} \\
{\left[\mathrm{mg} / \mathrm{m}^{3}\right]}\end{array}$ \\
\hline \multirow{3}{*}{1} & 0.1 & $\operatorname{lod}$ & $\operatorname{lod}$ & $\operatorname{lod}$ & $\operatorname{lod}$ \\
& 0.1 & $\operatorname{lod}$ & $\operatorname{lod}$ & $\operatorname{lod}$ & $\operatorname{lod}$ \\
& 0.1 & $\operatorname{lod}$ & $\operatorname{lod}$ & $\operatorname{lod}$ & $\operatorname{lod}$ \\
& 0.1 & $\operatorname{lod}$ & $\operatorname{lod}$ & 0.266 & $\operatorname{lod}$ \\
& 0.1 & 1.17 & $\operatorname{lod}$ & $\operatorname{lod}$ & $\operatorname{lod}$ \\
\hline \multirow{3}{*}{2} & 0.1 & $\operatorname{lod}$ & $\operatorname{lod}$ & $\operatorname{lod}$ & $\operatorname{lod}$ \\
& 0.1 & $\operatorname{lod}$ & $\operatorname{lod}$ & $\operatorname{lod}$ & $\operatorname{lod}$ \\
& 0.1 & $\operatorname{lod}$ & $\operatorname{lod}$ & $\operatorname{lod}$ & $\operatorname{lod}$ \\
& 0.1 & $\operatorname{lod}$ & $\operatorname{lod}$ & 0.266 & $\operatorname{lod}$ \\
& 0.1 & $\operatorname{lod}$ & $\operatorname{lod}$ & 0.266 & $\operatorname{lod}$ \\
\hline \multirow{3}{*}{3} & 0.1 & $\operatorname{lod}$ & $\operatorname{lod}$ & $\operatorname{lod}$ & $\operatorname{lod}$ \\
& 0.1 & $\operatorname{lod}$ & $\operatorname{lod}$ & 0.266 & $\operatorname{lod}$ \\
& 0.1 & $\operatorname{lod}$ & $\operatorname{lod}$ & 0.266 & $\operatorname{lod}$ \\
& 0.1 & $\operatorname{lod}$ & $\operatorname{lod}$ & 0.266 & $\operatorname{lod}$ \\
& 0.1 & 1.17 & $\operatorname{lod}$ & 0.266 & $\operatorname{lod}$
\end{tabular}

Measurements were taken at four control points. To compute the effective dose, we assumed the working time of $1800 \mathrm{~h}$, the sum of measured values and uncertainty involved in measurements being duly accounted for.

Table III summarizes the air composition data collected in the Lake Wessel Chamber. Measurements were repeated three times, in subsequent weeks. Measured parameters were the concentrations of: carbon dioxide $\mathrm{CO}_{2}[\%]$, carbon monoxide $\mathrm{CO}\left[\mathrm{mg} / \mathrm{m}^{3}\right]$, NO nitrogen oxide $\left[\mathrm{mg} / \mathrm{m}^{3}\right], \mathrm{SO}_{2}$ sulfur dioxide $\left[\mathrm{mg} / \mathrm{m}^{3}\right]$ and $\mathrm{H}_{2} \mathrm{~S}$ hydrogen sulfide $\left[\mathrm{mg} / \mathrm{m}^{3}\right]$.

Table IV gives the upper bounds of confidence levels, instantaneous concentrations and the sum total of exposure factor multiplicity involved in all measurements being taken: $\mathrm{CO}_{2}[\%], \mathrm{CO}\left[\mathrm{mg} / \mathrm{m}^{3}\right], \mathrm{NO}\left[\mathrm{mg} / \mathrm{m}^{3}\right], \mathrm{SO}_{2}$ $\left[\mathrm{mg} / \mathrm{m}^{3}\right], \mathrm{H}_{2} \mathrm{~S}\left[\mathrm{mg} / \mathrm{m}^{3}\right]$.

Air composition inside the Lake Wessel Chamber.

TABLE IV

\begin{tabular}{|c|c|c|c|c|}
\hline $\begin{array}{c}\text { Measurement } \\
\text { no }\end{array}$ & Factor & $\begin{array}{l}\text { Upper bound of the } \\
\text { confidence level }\end{array}$ & $\begin{array}{l}\text { Instantaneous } \\
\text { concentration }\end{array}$ & $\begin{array}{l}\text { Sum total of } \\
\text { exposure factor } \\
\text { multiplicity }\end{array}$ \\
\hline 1 & $\begin{array}{c}\mathrm{CO}_{2} \% \\
\mathrm{CO}\left[\mathrm{mg} / \mathrm{m}^{3}\right] \\
\mathrm{NO}\left[\mathrm{mg} / \mathrm{m}^{3}\right] \\
\mathrm{SO}_{2}\left[\mathrm{mg} / \mathrm{m}^{3}\right] \\
\mathrm{H}_{2} \mathrm{~S}\left[\mathrm{mg} / \mathrm{m}^{3}\right]\end{array}$ & $\begin{array}{c}0.1 \\
0.99 \\
\operatorname{lod}^{*} \\
0.25 \\
\text { lod } \\
\end{array}$ & $\begin{array}{c}0.1 \\
0.73 \\
\text { lod } \\
0.2 \\
\text { lod }\end{array}$ & 0.26 \\
\hline 2 & $\begin{array}{c}\mathrm{CO}_{2} \% \\
\mathrm{CO}\left[\mathrm{mg} / \mathrm{m}^{3}\right] \\
\mathrm{NO}\left[\mathrm{mg} / \mathrm{m}^{3}\right] \\
\mathrm{SO}_{2}\left[\mathrm{mg} / \mathrm{m}^{3}\right] \\
\mathrm{H}_{2} \mathrm{~S}\left[\mathrm{mg} / \mathrm{m}^{3}\right]\end{array}$ & $\begin{array}{l}0.1 \\
\text { lod } \\
\text { lod } \\
0.28 \\
\text { lod }\end{array}$ & $\begin{array}{l}0.1 \\
\text { lod } \\
\text { lod } \\
0.19 \\
\text { lod }\end{array}$ & 0.24 \\
\hline 3 & $\begin{array}{c}\mathrm{CO}_{2} \% \\
\mathrm{CO}\left[\mathrm{mg} / \mathrm{m}^{3}\right] \\
\mathrm{NO}\left[\mathrm{mg} / \mathrm{m}^{3}\right] \\
\mathrm{SO}_{2}\left[\mathrm{mg} / \mathrm{m}^{3}\right] \\
\mathrm{H}_{2} \mathrm{~S}\left[\mathrm{mg} / \mathrm{m}^{3}\right]\end{array}$ & $\begin{array}{c}0.1 \\
0.99 \\
\text { lod } \\
0.34 \\
\text { lod }\end{array}$ & $\begin{array}{c}0.1 \\
0.73 \\
\text { lod } \\
0.23 \\
\text { lod }\end{array}$ & 0.30 \\
\hline
\end{tabular}

\section{Discussion and results}

Measurements of potential energy concentrations $C \alpha$ were taken at four control points inside the Lake Wessel Chamber, as shown in Table II. Since it was extremely difficult to establish the exact times that people spend in particular sections of the chamber, the effective dose received by the personnel in a year is based on the mean concentration of potential energy $C \alpha$ in the escaping air stream, amounting to $0.493 \mu \mathrm{J} / \mathrm{m}^{3}$.

The yearly effective dose of alfa radiation threatening the people working in the gallery is computed, assuming the time they spend in this particular spot to be $1000 \mathrm{~h}$ yearly. The natural background within $1000 \mathrm{~h}$ approaches $0.274 \mathrm{mSv}$. The effective dose to which the personnel is exposed in the Lake Wessel Chamber is 
$0.416 \mathrm{mSv}$, the natural background being duly considered.

The heading in which the Lake Wessel Chamber is situated is not categorised in terms of radiation hazard as it is not monitored, because the yearly effective dose shall not exceed $1 \mathrm{mSv}$. When categorising mine headings and galleries in terms of radiation hazard, the real working time is considered (though no less than $1800 \mathrm{~h}$ ) and the natural background levels are subtracted. On the other hand, while assessing the radiation exposure, we take into account the real time spent by people in the given gallery or heading.

Under art. 2.1. of the regulation by the Council of Ministers of 18th Jan 2005 concerning the admissible doses of ionizing radiation (Journal of Laws no 20, 3rd Feb 2005, item 168), the maximal admissible dose expressed as the effective dose equals $20 \mathrm{mSv}$ during the whole calendar year.

Air composition measurements $\left(\mathrm{CO}, \mathrm{CO}_{2}, \mathrm{SO}_{2}, \mathrm{NO}\right.$, $\mathrm{H}_{2} \mathrm{~S}$ ) in the Lake Wessel Chamber yield the instantaneous concentrations and the upper bound of the confidence level GGw, i.e. the parameter comparable to the admissible concentrations of these substances in the atmosphere. The sum total of the exposure factor multiplicity is obtained, too. The contents of harmful substances proved to be less than NDS whilst the sum total of the exposure factor multiplicity is less than 1 .

\section{References}

[1] M. Skulimowski, Przeglad lekarski 4-5, 225 (1964).

[2] M. Skulimowski, Przeglad lekarski 8, 615 (1967).

[3] M. Skulimowski, Annals of Allergy 26, 66 (1968).

[4] A. Bogdanowicz, N. Skiepian, A. Szpakow, Acta Pneumonol. Allegol. Pediatr. 6, 28 (2003).

[5] Obtułowicz, Przeglad Lekarski 56, 1 (1999).

[6] A. Szczeklik, A. Tondryk, K. Obtułowicz, I. Wróblewska, Problemy Uzdrowiskowe 121, 35 (1979). 